\title{
Editorials
}

\section{Conflict of interest: What's a journal to do?}

Andrew S. Wechsler, MD

From Drexel University College of Medicine, Philadelphia, Pa.

Received for publication Feb 13, 2006; accepted for publication Feb 13, 2006.

Address for reprints: Andrew S. Wechsler, MD, Drexel University College of Medicine, 245 North 15th St, Room 6415, Philadelphia, PA 19102-1192 (E-mail: jtcvs@ drexelmed.edu).

J Thorac Cardiovasc Surg 2006;131:771-2 0022-5223/\$32.00

Copyright $\odot 2006$ by The American Association for Thoracic Surgery

doi:10.1016/j.jtcvs.2006.02.007

\section{Addendum}

Subsequent to the writing of this editorial, I was contacted by the president of Estech, Inc. I was pleased to learn that Estech has enacted a new policy regarding disclosure of relationships that others might interpret as conflicts of interest. Specifically, I believe they have set a high watermark for industry: Their new consulting agreements require disclosure of this relationship on material that their consultants submit for publication or presentation; failure of the consultant to so indicate the relationship is grounds for nonpayment of either honoraria or grants. It is gratifying to see the conflict of interest issue being addressed in such a proactive fashion.
I $\mathrm{n}$ recent weeks, your Editor became involved in a lengthy series of E-mails and telephone conversations with a reporter from The Wall Street Journal. It seems that three articles were published by us in which the authors had clear conflicts of interest (COI) that we did not report. In one case, we failed to transmit potential conflicts disclosed by the authors. In the other two instances, my interpretation is that serious potential COIs were withheld from the Journal at the time of submission. One author had an important financial relationship with AtriCure (Cincinnati, Ohio) that he chose not to disclose. In the other instance, far more complex relationships existed that ranged from consulting agreements by some authors to authors having control over financial investments that might have profited from increased value of AtriCure stock. Both articles, regardless of how egregious the violations of our policy, survived careful peer review and generated work deemed meritorious.

As a result of this experience, I was forced to reconsider the Journal's COI policy and refresh my own knowledge of the issue. It is not my purpose in this editorial to explore the many facets of the COI controversy because the issue has been discussed at length by scientists, ethicists, politicians, national medical leaders, and the press. The evidence seems pretty strong to me that important financial interests in the outcomes and interpretations of studies can influence those interpretations. For the time being, I do not subscribe to the philosophy that these conflicts invalidate the work. I do, however, believe that reviewers and readers have a right to be forewarned that a potential bias might exist. I also believe that determination of whether or not a conflict exists should not be in the hands of the potentially conflicted.

Richard Smith, former Editor of the BMJ (British Medical Journal), has written thoughtfully on this topic. I like his conclusive statement that "conflict of interest is a condition not a behaviour." That being the case, asking an author to determine whether she had a COI is analogous to the adage that "a doctor who treats himself has a fool for a doctor." We do not ask authors to manage their COI nor to declare one. We ask only that they disclose to us all their relationships with industry and those of their coauthors. We accept the responsibility for using those disclosures to unveil a potential COI; that is, we use the objective disclosures to make a diagnosis and, as a remedy, we publish the existence of a relationship that could be construed as a COI.

My editorial staff, associate editors, reviewers, and editorial board members are not police officers. We assume that authors are inherently honest and forthcoming with required information. We assume that their institutions have policies that manage COI before research, human or otherwise, is allowed. What we have never done is to punish authors who violate our disclosure policies, and I was astonished to learn that no systematic penalties exist for such devious behavior. Thus, at its last Council meeting, The American Association for Thoracic Surgery agreed with a proposal from me to deny authors who violate our disclosure policy the privilege of publishing their work in our Journal for some period of time, probably one to two years. This solution is not perfect but it is practical. In some instances, we will be 
punishing our readers as much as sneaky authors. I think, however, that the message is clear: We take disclosure of relationships that might influence article content very seriously.

As does every student of the issue of COI, I know that this approach is not enough. What about our reviewers? Are they in competition with the author of an article they review? Does personal animosity exist? Is there potential gain to the reviewer by looking favorably on certain work? How can a pragmatic approach to running the Journal be balanced with these incredibly complex issues?

I have decided to make two important changes in Journal policy to try to manage these issues. First, we will ask all reviewers that which we should not ask of them: "Does this article in any way raise the potential of a conflict of interest?" We are also going to incorrectly allow the reviewer to manage that potential conflict by stating that he or she does not believe any potential conflict prohibits him or her from providing a good, scientifically valid review. Ultimately, all reviews are judged by me and my associate editors in the context of other reviews and of our own impressions of the submitted work.

Second, and more important, we have established a formal system for managing disclosures. Led by our ethics editor, Dr Martin McKneally, we are convening a panel whose members will review the disclosures of all authors as they relate to any article accepted for publication. When the ethics panel believes a conflict exists, we will publish the disclosures of the authors.

Finally, we must acknowledge that every system remains at the mercy of our authors and of our belief in the inherent honesty and desire to "do the right thing" that has been a hallmark of our profession and specialty over the years. We assert the belief that our authors are persons of character and accept the notion that character is doing the right thing when no one is looking. If an author offends us by displaying a lack of character, we believe our disciplinary action is appropriate.

\section{Bibliography}

Brennan T, Rothman D, Blank L. Health industry practices that create conflicts of interest. JAMA. 2006;295:429-33.

Smith R. Beyond conflict of interest. BMJ. 1998;317:291-2.

Stossel T. Regulating academic-industrial relationshipssolving problems or stifling progress. $N$ Engl $\mathrm{J}$ Med. 2006;335:1060-5.

\section{Notices of Correction}

In the June 2005 issue of the Journal, the article by Dr. Gillinov and associates titled "Surgical ablation of atrial fibrillation with bipolar radiofrequency as the primary modality" (2005;129:1322-9) contained incomplete disclosure statements. Dr. Gillinov provided the following additional information: Drs. McCarthy and Gillinov were consultants to Atricure, Inc when the manuscript was written. Dr. Gillinov has no equity interest in Atricure, Inc. At the time of manuscript submission, Dr. McCarthy did not have an equity interest in Atricure, Inc. Dr. Cosgrove previously served on the Board of Directors of Atricure, Inc. The Cleveland Clinic has an interest in a venture capital fund which has an investment in Atricure, Inc.

In the October 2004 issue of the Journal, pursuant to the article by Dr. Gaynor and associates titled "A prospective, single-center clinical trial of a modified Cox maze procedure with bipolar radiofrequency ablation" (2004;128:535-42), the authors disclosed to the Journal that Dr. Schuessler and Dr. Damiano were consultants to Atricure, Inc. The Journal did not include this information with the article. In a follow-up inquiry, Dr. Damiano indicated that his disclosure and that of Dr. Schuessler were complete and that neither had stock ownership, equity interest, or patient license arrangements with Atricure.

In the September 2005 issue of the Journal, pursuant to the article by Dr. Wolf and associates titled "Video-assisted bilateral pulmonary vein isolation and left atrial appendage exclusion for atrial fibrillation" (2005;130:797-802), the authors disclosed in their initial cover letter to the Journal only that Drs. Schneeberger, Gillinov and Wolf received educational grants from Atricure that were not used to fund this research. In a follow-up response to further inquiry, Dr. Wolf disclosed the following information: He was, at the time of manuscript submission, a consultant to Atricure and had equity interests in the form of option shares and warrants that were less than $0.5 \%$ ownership of the company. Dr. Gillinov was a consultant to Atricure in November of 2004. Dr. Schneeberger was a consultant in November of 2004 and had equity interests consisting of option shares in the company that were less than $0.5 \%$ ownership of the company. Dr. Flege is a member of the Event Adjudication Committee of Atricure, is paid by the hour and worked a total of one hour during the last 2 years. 